\title{
Interpretation of Soil Carbon and Nitrogen Dynamics in Agricultural and Afforested Soils
}

\author{
E. A. Paul,* S. J. Morris, J. Six, K. Paustian, and E. G. Gregorich
}

\begin{abstract}
Interpretation of soil organic C (SOC) dynamics depends heavily on analytical methods and management systems studied. Comparison of data from long-term corn (Zea mays)-plot soils in Eastern North America showed mean residence times (MRTs) of SOC determined by ${ }^{14} \mathrm{C}$ dating were 176 times those measured with ${ }^{13} \mathrm{C}$ abundance following a 30-yr replacement of $\mathrm{C}_{3}$ by $\mathrm{C}_{4}$ plants on the same soils. However, MRTs of the two methods were related $\left(r^{2}=0.71\right)$. Field ${ }^{13} \mathrm{C}$ MRTs of SOC were also related $\left(R^{2}=0.55\right.$ to 0.85$)$ to those measured by ${ }^{13} \mathrm{CO}_{2}$ evolution and curve fitting during laboratory incubation. The strong relations, but different MRTs, were interpreted to mean that the three methods sampled different parts of a SOC continuum. The SOC of all parts of this continuum must be affected by the same controls on SOC dynamics for this to occur. Methods for site selection, plant biomass, soil sampling and analysis were tested on agricultural, afforested-agriculture, and native forest sites to determine the controls on SOC dynamics. Soil-C changes after afforestation were -0.07 to $0.55 \mathrm{Mg} \mathrm{C} \mathrm{ha}^{-1} \mathrm{yr}^{-1}$ on deciduous sites and -0.85 to $0.58 \mathrm{Mg} \mathrm{C} \mathrm{ha}^{-1} \mathrm{yr}^{-1}$ under conifers. Soil $\mathrm{N}$ changes under afforestation ranged from -0.1 to $0.025 \mathrm{Mg} \mathrm{N} \mathrm{ha}^{-1} \mathrm{yr}^{-1}$. Ecosystem $\mathrm{N}$ accumulation was -0.09 to $0.08 \mathrm{Mg} \mathrm{N} \mathrm{ha}^{-1} \mathrm{yr}^{-1}$. Soil $\mathrm{C}$ and $\mathrm{N}$ sequestration but not plant biomass were related to soil $\mathrm{Ca}, \mathrm{Mg}$, and $\mathrm{K}$ contents. Comparative, independent assays of long-term plots provides information for concept testing and the confidence necessary for decision-makers determining $\mathrm{C}$-cycle policies.
\end{abstract}

$\mathrm{T}$ HE ACCUMULATION AND TURNOVER of soil organic matter (SOM) is a major factor in soil fertility and ecosystem functioning and determines whether soils act as sinks or sources of $\mathrm{C}$ in the global $\mathrm{C}$ cycle (Post and Kwon, 2000). Soil organic matter dynamics are complex, involving a wide array of organic constituents (Sollins et al., 1999) with MRTs that range over three orders of magnitude (Goh et al., 1989; Paul et al., 2001a). The results are most useful if standardized sampling techniques and analyses are combined with available tracers across a number of long-term experiments or chronosequence sites.

Determining the impacts of management on soil $\mathrm{C}$ and $\mathrm{N}$ accumulation is hindered by the small amounts sequestered annually relative to the large pools in the soil as well as the considerable spatial heterogeneity of SOM (Morris, 1999; Stoyan et al., 2000; Mulla and McBratney, 2000). This heterogeneity, can in a large

E.A. Paul, J. Six, and K. Paustian, Natural Resource Ecology Lab., Colorado State Univ., Ft. Collins, CO 80523; S.J. Morris, Dep. of Biology, Bradley Univ., Peoria, IL 61625; E.G. Gregorich, Eastern Cereal and Oilseed Research Centre, Agriculture Canada, Ottawa, ON KJA OC6, Canada; J. Six, Present Address: Dep. of Agronomy and Range Science, Univ. of California, Davis CA 95616. Received 11 Feb. 2002. *Corresponding author (eldor@nrel.colostate.edu).

Published in Soil Sci. Soc. Am. J. 67:1620-1628 (2003).

(c) Soil Science Society of America

677 S. Segoe Rd., Madison, WI 53711 USA part, be attributed to environmental impacts on the controls on SOM dynamics that exist on these sites. It is impossible to sample the many sites, soil types, management regimes, landscapes, and climatic regimes in enough detail to inform decision-makers on issues such as $\mathrm{C}$ sequestration. Methods that incorporate the key factors controlling soil $\mathrm{C}$ and $\mathrm{N}$ dynamics (Fig. 1) need to be validated from detailed site measurements. To be useful for answering today's questions on the potential for $\mathrm{C}$ sequestration with regard to global change, models that predict pool sizes and turnover rates, and thus overall $\mathrm{C}$ dynamics, must be based on verifiable, analytically derived data.

Tracers of $\mathrm{C}$ have provided a great deal of information on SOC dynamics (Coleman and Fry, 1991). Carbon dating of ${ }^{14} \mathrm{C}$, occurring in the atmosphere and incorporated into plant components through photosynthesis (Campbell et al., 1967; Trumbore et al., 1996), provides a useful but expensive tracer. Discrimination against atmospheric ${ }^{13} \mathrm{CO}_{2}$ during plant photosynthesis provides another signal (Boutton, 1996). Plants with a $\mathrm{C}_{3}$ pathway, such as most trees and crops (wheat [Triticum aestivum L.], soybeans [Glycine max L.], cool season grasses), result in more negative ${ }^{13} \mathrm{C}$ plant residues than $\mathrm{C}_{4}$ plants such as corn or warm season grasses. This signal can be used to follow SOM dynamics if natural succession, or management, has resulted in a plant switch such as the growth of $\mathrm{C}_{4}$ corn on previously $\mathrm{C}_{3}$ forest soil or on soil that has grown primarily $\mathrm{C}_{3}$ crops.

Soil organic matter is comprised of a continuum of materials that range in MRTs of days and months through decades, centuries, and millennia. The MRT of the labeled soil components is dependent both on resistance to decay and extent of protection against decomposition. The length of time that the label has been in the soil affects the distribution of the tracer through different SOM components and strongly influences MRT estimates. Short-term experiments with artificially added tracers produced in the laboratory (Coleman and Fry, 1991) and followed in the field for 1 to $2 \mathrm{yr}$ most often yield results with MRTs of months to a few years regardless of tracer employed. The ${ }^{13} \mathrm{C}$ plant-switch methods often use experiments that have been in place for decades. They produce results in this time frame (Six and Jastrow, 2002). Carbon dating shows much greater ages with some SOC being thousands of years old (Paul et al., 2001b).

The dynamics of SOC can also be measured by soil incubation in the laboratory to allow biological mineralization of C. Curve analysis of $\mathrm{CO}_{2}$ evolution rates, over

Abbreviations: MRT, mean residence time; SOC, soil organic C; SOM, soil organic matter. 


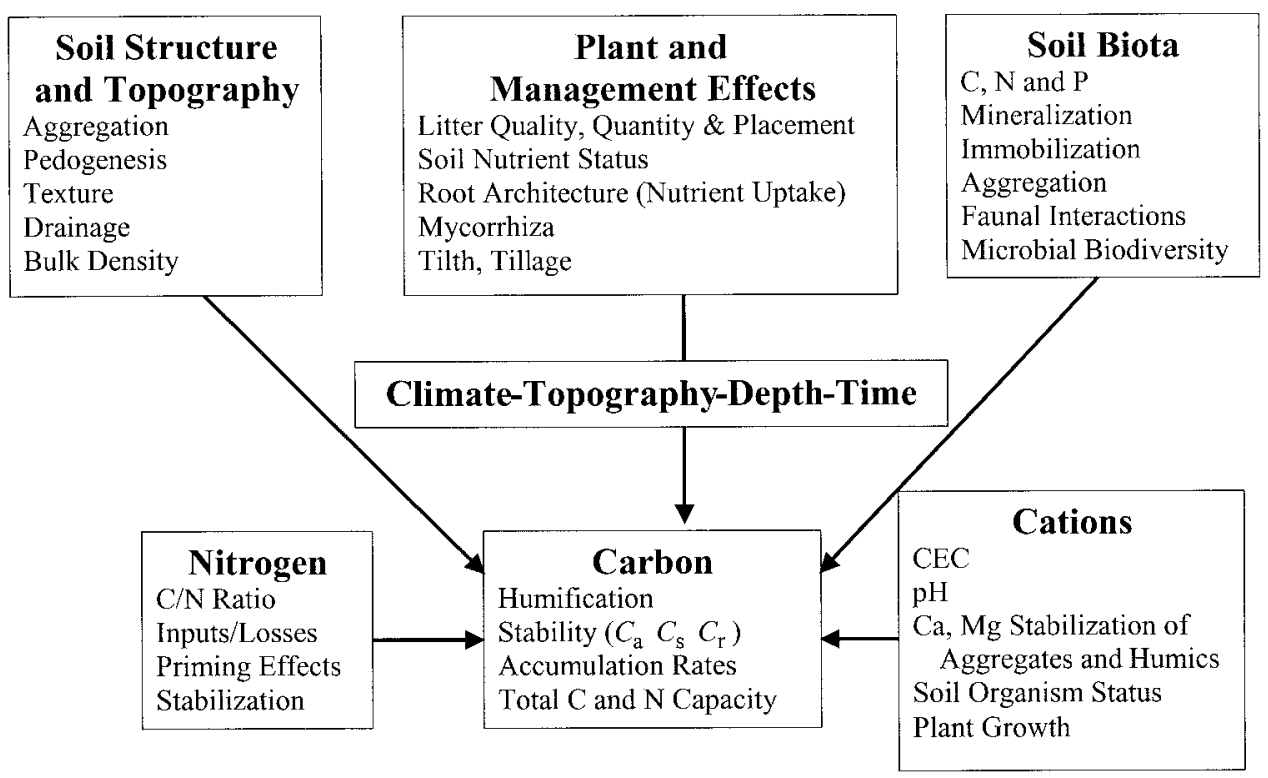

Fig. 1. Process controls of soil organic matter dynamics.

time, is combined with acid hydrolysis and ${ }^{14} \mathrm{C}$ dating to estimate the MRTs of active, slow, and resistant SOC pools (Paul et al., 2001b). The active fraction has MRTs of months. The slow pool represents material that has been in the soil often for decades. The resistant pool, often 1400 yr older than the total soil (Paul et al., 2001a) represents millennia of pedogenesis. The pools are comprised of a range of materials because of the continuous nature of addition, stabilization, and decomposition of SOM. One objective of this paper was to reexamine published estimates of SOM turnover obtained by three methods to see whether these methods yielded consistent patterns that could be used to interpret SOC dynamics. To do this, we reanalyzed data on ${ }^{14} \mathrm{C}$ dating (Paul et al., 2001a), field- ${ }^{13} \mathrm{C}$ analysis (Collins et al., 1999) and long-term incubation data (Collins et al., 2000) obtained from the same soil samples on long-term experiments in the U.S. Corn Belt.

Forested soils present major analytical problems in determining SOM dynamics and estimating rates of soil $\mathrm{C}$ change with land use conversions from agriculture to forest. There are rarely replicated long-term experiments of the effects of land-use change and/or management. Trees growing in eastern North America on afforested sites that were in mixed cropping regimes during their cultivation period often do not provide a useful ${ }^{13} \mathrm{C}$ signals for estimating turnover rates. Thus, the dominant methodology is a 'paired-plot' design, with identification of adjacent fields, on the same soil type, for comparative, chronosequence studies. For such studies, selection of the areas to be compared and the method of sampling are important issues. The second objective of this paper was to investigate the effects of afforestation on soil $\mathrm{C}$ and $\mathrm{N}$ dynamics. We compared soil $\mathrm{C}$ and $\mathrm{N}$ stocks in agricultural, afforested, and native forest sites to estimated rates of soil $\mathrm{C}$ change as a consequence of conversion of agricultural lands to forests. As the isotopic methods used in the long-term agricultural experiments could not be used to investigate SOM turnover rates, we measured other factors with known impacts on SOM accumulation, turnover and stabilization. These measurements included forest biomass, soil nutrients, texture, and pH. Early studies (Jenny, 1941; Kononova, 1966) and recent work (Baldock and Nelson, 2000; Clough and Skjemstad, 2000) highlight the importance of $\mathrm{Ca}$ in SOM stabilization. We therefore related the effects of $\mathrm{Ca}$ and other nutrients to SOM sequestration on afforestation.

\section{MATERIALS AND METHODS}

\section{Interpretation of Methodology Using Agricultural Soils and Tracers}

Published data produced using three, independent techniques to measure SOM dynamics were compared. This included: (i) results of ${ }^{14} \mathrm{C}$ dating and acid hydrolysis combined with dating (Paul et al., 2001a), (ii) ${ }^{13} \mathrm{C}$ soil analysis after $\mathrm{C}_{3} \leftrightarrow \mathrm{C}_{4}$ photosynthesis-type plant switches and measurement of the SOC derived from $\mathrm{C}_{3}$ or $\mathrm{C}_{4}$ residues (Collins et al., 1999), and (iii) analysis of $\mathrm{CO}_{2}$ mineralization kinetics (Collins et al., 2000). The MRTs measured with the three methods were compared by regression analysis to determine if independent approaches for evaluating $\mathrm{C}$ dynamics on the same soil samples showed a discernible pattern across sites. The sites represented a range of soil types, textures, and climate (Table 1). Soils were sampled using six $5.4-\mathrm{cm}$ diameter cores per replicate and four replicates per site. Samples, from replicated plots, were randomly taken using a hydraulic coring device and were separated into 0 - to 20-, 20- to 25-, 25- to 50-, and 50- to 100-cm depths before compositing (Collins et al., 1999; Paul et al., 2001a).

Organic matter pool sizes and fluxes were calculated using a three-pool model,

$$
C_{\mathrm{t}}=C_{\mathrm{a}} \exp \left(-k_{\mathrm{a}} t\right)+C_{\mathrm{s}} \exp \left(-k_{\mathrm{s}} t\right)+C_{\mathrm{r}} \exp \left(-k_{\mathrm{r}} t\right) \quad[1]
$$

where $C_{\mathrm{a}}, C_{\mathrm{s}}$, and $C_{\mathrm{r}}$ were defined as the initial (preincubation) 


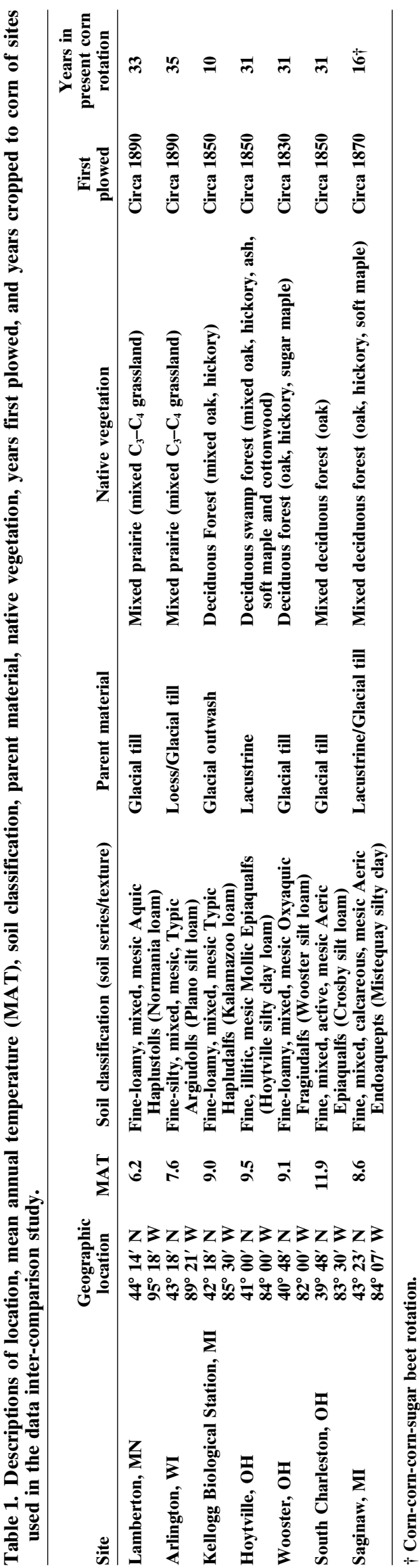

active, slow, and resistant fractions. Corresponding decay rates

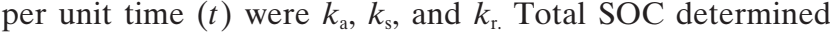
on dried soil (Paul et al., 2001b) corresponded to $C_{\mathrm{t}}$. The amount of the SOC resistant to $6 \mathrm{M} \mathrm{HCl}$ hydrolysis (Leavitt et al., 1997; Paul et al., 2001a) determined the size of the resistant pool $\left(C_{\mathrm{r}}\right)$. The MRT, measured by ${ }^{14} \mathrm{C}$ dating (Goh et al., 1989), determined its kinetics $\left(C_{\mathrm{r}} \exp \left[-k_{\mathrm{r}} t\right]\right)$. The ${ }^{13} \mathrm{C}$ measurements on the same soils (Collins et al., 1999) were based on a $\mathrm{C}_{3} \leftrightarrow \mathrm{C}_{4}$ plant-photosynthesis type switch. These were in place for $35 \mathrm{yr}$ in the Wisconsin site, $33 \mathrm{yr}$ in Minnesota, $31 \mathrm{yr}$ in the Ohio sites, $16 \mathrm{yr}$ at Saginaw, MI and $10 \mathrm{yr}$ at Kellogg Biological Station, MI (Table 1). Plants involved on agricultural soils were alfalfa (Medicago sativa L.), corn (Zea mays L.), soybean, sugar beet (Beta vulgaris L.) and wheat.

The mineralization of SOC, as measured by $\mathrm{CO}_{2}$ release during 1000- to $1200-\mathrm{d}$ incubation was used to characterize the size and dynamics of the active $\left(C_{\mathrm{a}}\right)$ and slow pool $\left(C_{\mathrm{s}}\right)$ (Collins et al., 2000). Field moist soils, adjusted to $60 \%$ water holding capacity, were incubated at $25^{\circ} \mathrm{C}$ (Collins et al., 2000). Infrared analysis of the headspace gas of incubated soils, controls and $\mathrm{CO}_{2}$ calibration gas was used to determine $\mathrm{CO}_{2}$ evolution. At least 10 incubation periods were used for nonlinear regression analysis that corrected for the curvilinear relationship of the $\mathrm{CO}_{2}$ evolution between sampling points (PROC NLIN; SAS, 1995). This calculated the kinetics of the active pool $\left(C_{\mathrm{a}} \exp \left[-k_{\mathrm{a}} t\right]\right)$ and the slow pool $\left(C_{\mathrm{s}} \exp \left[-k_{\mathrm{s}} t\right]\right)$. Mass spectrometric analysis of the evolved $\mathrm{CO}_{2}$ made possible the calculation of the kinetics of the total $\mathrm{CO}_{2}$ as well as the ${ }^{13} \mathrm{CO}_{2}$ evolved over time (Collins et al., 2000). The active $\left(\mathrm{C}_{\mathrm{a}}\right)$ and slow $\left(C_{\mathrm{s}}\right)$ pools were estimated from the respiration curves after subtracting $C_{\mathrm{r}}$ (the non-hydrolyzable fraction) from $C_{\mathrm{t}}$ (Paul et al., 2001b). Turnover was expressed as MRT (1/k) as in first-order kinetics at steady state (Paul et al., 2001b).

\section{Soil Organic Matter Measurements for Evaluating Impacts of Afforestation}

We compared above and belowground plant biomass and soil $\mathrm{C}$ on three locations with agricultural, afforested, and native sites on the same soil type (Table 2). The ${ }^{13} \mathrm{C}$ method could not be used on these sites because of the lack of an adequate tracer; results from ${ }^{14} \mathrm{C}$ dating and long-term incubation are not yet available. Sequestration calculations were based on the assumption that current agricultural sites at the time of sampling contained $\mathrm{C}$ and $\mathrm{N}$ contents representative of the fields before tree planting. The use of sites where afforestation was done for conservation or administrative reasons ensured that afforested land was not abandoned farmland of different quality than the surrounding area. Management information suggests no fertilizer usage on the afforested and forested sites. Plants involved in the afforestation study involved ash (Fraxinus spp.), cedar (Juniperus virginiana L.), cherry (Prunus serotina Ehrh.), cottonwood (Populus deltoides Marsh.), hickory (Carya spp.), maple (Acer spp.), oak (Quercus spp.), poplar (Populus spp.), red pine (Pinus resinosa Ait.), scotch pine (Pinus sylvestris L.), and walnut (Juglans nigra L.). The trees, aspen (Populus tremuloides Michx), and birch (Betula papyrifera Marsh.) were mentioned relative to the literature and are described there, as are the earthworms (Lumbricus spp.).

The Ohio sites were sampled to a depth of $100 \mathrm{~cm}$, by compositing (Boone et al., 1999) three samples obtained with a 5 -cm diameter soil corer driven in with a hammer and removed with the aid of a tripod. There were two transects per tree taken $0.5,1$, and $1.5 \mathrm{~m}$ from the base of each of three trees to minimize impacts of single tree influence zones (Zinke, 1962). One tree species was sampled per site (Table 2) to 
Table 2. Descriptions of location, mean annual temperature (MAT), soil classification, afforested vegetation, afforested vegetation sampled, native vegetation, and agricultural rotations for sites included in afforestation study.

\begin{tabular}{|c|c|c|c|c|c|c|c|}
\hline Site & $\begin{array}{c}\text { Geographic } \\
\text { location }\end{array}$ & MAT & $\begin{array}{c}\text { Soil } \\
\text { classification } \\
\text { (soil series/texture) }\end{array}$ & $\begin{array}{l}\text { Afforested } \\
\text { vegetation }\end{array}$ & $\begin{array}{c}\text { Afforested } \\
\text { vegetation } \\
\text { sampled }\end{array}$ & $\begin{array}{c}\text { Native } \\
\text { vegetation }\end{array}$ & Agriculture \\
\hline Kemptville, ONT & $\begin{array}{l}4^{\circ} 01^{\prime} \mathbf{N} \\
7^{\circ} \mathbf{3 8}^{\prime} \mathbf{W}\end{array}$ & 5.8 & $\begin{array}{l}\text { Melanic Brunisol } \dagger \\
\text { (Grenville sandy loam) }\end{array}$ & $\begin{array}{l}\text { Deciduous-maple } \\
\text { Planted } 1977 \\
\text { Conifer-red pine } \\
\text { Planted } 1971\end{array}$ & $\begin{array}{l}\frac{\text { Deciduous }}{\text { maple }} \\
\frac{\text { Conifer }}{\text { red pine }}\end{array}$ & $\begin{array}{l}\text { poplar, pine, } \\
\text { birch, cedar }\end{array}$ & $\begin{array}{l}\text { alfalfa, corn } \\
\text { rotation }\end{array}$ \\
\hline Maumee, ОH & 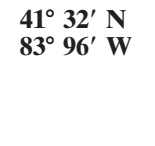 & 9.1 & $\begin{array}{l}\text { Mixed, mesic Aquic } \\
\text { Udipsamments } \\
\text { (Ottokee fine sand) }\end{array}$ & $\begin{array}{l}\text { Deciduous-Mixed } \\
\text { deciduous species } \$ \\
\text { Planted 1950 } \\
\text { Conifer-scotch pine } \\
\text { Planted 1950 }\end{array}$ & $\begin{array}{l}\frac{\text { Deciduous }}{\text { oak }} \\
\frac{\text { Conifer }}{\text { red pine }}\end{array}$ & oak, cherry & $\begin{array}{l}\text { corn, soybean } \\
\text { rotation }\end{array}$ \\
\hline Delaware, OH & $\begin{array}{l}40^{\circ} 24^{\prime} \mathrm{N} \\
8^{\circ} \mathbf{0 1}^{\prime} \mathrm{W}\end{array}$ & 10.8 & $\begin{array}{l}\text { Fine, illitic, mesic Typic } \\
\text { Hapludalf } \\
\text { (Morley silt loam) }\end{array}$ & $\begin{array}{l}\text { Deciduous-Mixed } \\
\text { deciduous species§ } \\
\text { Successional circa } 1950\end{array}$ & $\frac{\text { Deciduous }}{\text { maple }}$ & $\begin{array}{l}\text { Maple, hickory, } \\
\text { walnut, ash, } \\
\text { oak, cherry }\end{array}$ & $\begin{array}{l}\text { corn, soybean } \\
\text { rotation }\end{array}$ \\
\hline
\end{tabular}

$\dagger$ Great group-Canadian-U.S. equivalent $=$ Eutrochrepts or Cryochrepts or Hapludolls.

+ Oak, tulip poplar, cherry.

$\S$ Maple, elm, walnut, buckeye, ash, basswood.

minimize differences in soil $\mathrm{C}$ associated with specific tree effects (Boerner and Koslowsky, 1989). With the exception of successional stands, most afforested stands were planted in rows and sampling designs that were unbiased by differences in tree distribution were used.

Agricultural soils, used for comparison in the afforestation study, were sampled to a depth of $100 \mathrm{~cm}$ with a 5-cm diameter hydraulic-mounted soil corer. Three cores were composited from each of three locations selected in the center of an agricultural field no less than $25 \mathrm{~m}$ apart within a 2-ha area. At Kemptville, Ontario, all soils were sampled from three $0.5-\mathrm{m}^{2}$ soil pits on representative soil types (Ellert and Gregorich, 1996). Soils were sampled by horizon at all sites. Samples used in the afforested soil study were analyzed after sieving, compositing, and drying. Bulk density was measured by determining soil core volume and weight of individual soil cores. Gravimetric water content was used to calculate dry bulk density. Dry bulk density at Kemptville was determined by the core method for bulk density (Elliott et al., 1999).

Texture was determined by dispersing $30 \mathrm{~g}$ of air-dried soil in $100 \mathrm{~mL}$ of $5 \%(\mathrm{wt} / \mathrm{v})$ sodium hexametaphosphate solution and shaking for $18 \mathrm{~h}$ (Cambardella and Elliott, 1992). The soil solution was passed through a $53-\mu \mathrm{m}$ sieve and sand retained on the sieve was determined gravimetrically. Material passing though the sieve was placed in sedimentation columns and clay content was determined with a hydrometer; silt content was calculated by difference. The soils for $\mathrm{C}$ and $\mathrm{N}$ analysis were ground to pass a $180-\mu \mathrm{m}$ screen and analyzed by dry combustion in a Carlo Erba $\mathrm{CN}$ analyzer using calibration standards and soil controls (Sollins et al., 1999). Inorganic C, in samples from Kemptville and Delaware, was removed by subjecting moist soils in silver sample cups to an $\mathrm{HCl}$ atmosphere in a desiccator for $18 \mathrm{~h}$ (Paul et al., 2001b). For analysis in a soil testing laboratory, soils were extracted with $1.0 \mathrm{M}$ $\mathrm{COOCH}_{3} \mathrm{NH}_{4}$ and extractable $\mathrm{Ca}, \mathrm{K}$, and $\mathrm{Mg}$ were determined on an atomic absorption/emission spectrometer (Warncke and Brown, 1998). Available P was determined using the Bray and Kurtz P-1 Test on acidic soils and the Olsen Method for calcareous soils (Frank et al., 1998). Bulk density and horizon depth were used to express data on a mass equivalent to the native soil to depth of $1 \mathrm{~m}$ (Ellert and Gregorich, 1996; Six et al., 2002).

Random 25 by $50 \mathrm{~m}$ plots were established in forest sites and diameter at breast height was recorded for trees within the plot by species. Tree biomass was determined by species, using equations derived for trees in that region (Tritton and Hornbeck, 1982). Tree biomass was converted to above and below ground biomass $\mathrm{C}$ using conversion factors for each region derived by Birdsey (1992). Tree biomass $\mathrm{N}$ was calculated from biomass $\mathrm{C} / \mathrm{N}$ contents for deciduous and coniferous species independently (Kaczmarek et al., 1995; Pregitzer and Palik, 1997).

\section{RESULTS \\ Interpretation of Methodology using Agricultural Soils and Tracers}

The MRT of the $\mathrm{C}_{3}$ (non corn-derived) SOC determined by laboratory incubation, $\mathrm{CO}_{2}$ evolution and mass spectrometry was correlated $\left(r^{2}=0.55\right)$ with that of the same soil samples analyzed directly for ${ }^{13} \mathrm{C}$ (Table 3). The MRT obtained by incubation was 33\% of that measured directly in total SOC of field samples with ${ }^{13} \mathrm{C}$ methodology. Removal of the data set with high, atypical SOC levels (Hoytville, $\mathrm{OH}$ ) raised the regression between the incubation and the ${ }^{13} \mathrm{C}$-field analysis from an $r^{2}$ of 0.55 to 0.85 but only changed the slope of the line from 0.33 to 0.27 (Table 3 ). The soils from the long-term experiments were also ${ }^{14} \mathrm{C}$ dated, allowing a comparison of the results from ${ }^{14} \mathrm{C}$ dating with those of the $\mathrm{C}_{3} \leftrightarrow \mathrm{C}_{4}$ plant switch and ${ }^{13} \mathrm{C}$ measurements. Carbon dates were related to the ${ }^{13} \mathrm{C}$ data $\left(r^{2}=0.71\right)$ with a curvilinear equation (Table 3 ) but were 176 times as old as the MRT of ${ }^{13} \mathrm{C}$, non-corn SOC. Differences in MRTs are attributable to the fact that the 10 to $35 \mathrm{yr}$ ${ }^{13} \mathrm{C}$ exposures labeled primarily the active and slow pool whereas ${ }^{14} \mathrm{C}$ dating included the resistant component of the SOC continuum.

Table 3. Interrelationship of different methods of measuring mean residence time (MRT) in soil $\mathrm{C}$ pools $\dagger$.

\begin{tabular}{llc}
\hline & Equation $\$$ & $r^{2}$ \\
\hline a. & ${ }^{13} \mathrm{CO}_{2}$ MRT $\$=\mathbf{0 . 3 3} \mathrm{C}_{3}$ field MRTI +3.34 & $\mathbf{0 . 5 5}$ \\
b. & ${ }^{13} \mathrm{CO}_{2}$ MRT $\$=\mathbf{0 . 2 7} \mathrm{C}_{3}$ field MRTI $+\mathbf{3 3 . 4}$ & $\mathbf{0 . 8 5}$ \\
c. & ${ }^{14} \mathrm{C}$ MRT\# $=\mathbf{1 7 6}\left(\mathrm{C}_{3}\right.$ field MRTI) ${ }^{0.54}$ & $\mathbf{0 . 7 1}$ \\
\hline
\end{tabular}

$\uparrow \mathrm{C}$ pools include field $\mathrm{C}_{3}$ with (Eq. [a]) and without (Eq. [b]) Hoytville, MRT of ${ }^{13} \mathrm{C}\left(\mathrm{C}_{4} \leftrightarrow \mathrm{C}_{3}\right.$ Switch) and ${ }^{14} \mathrm{C}$ of total $\mathrm{C}(\mathrm{Eq}$. [c] ).

$\mp$ Equations $a$, and $b$ in the slope-intercept form $y=m x+b$, and Eq. [c] in the form $y=a x^{n}$.

$\S$ Calculated from long-term incubations.

II Measured on the samples before incubations.

\# MRT calculated from ${ }^{14} \mathrm{C}$ dating. 


\section{Soil Organic Matter Measurements for Evaluating Impacts of Afforestation}

The Maumee, Ottokee fine sand contained the lowest SOC, the Kemptville, Greenville sandy loam was intermediate and the Morley silt loam at the Delaware site was highest in SOC (Table 4) underscoring the general controls of texture on SOC contents. Subtraction of the agricultural from the afforested and dividing by the years since afforestation gave soil $\mathrm{C}$ and $\mathrm{N}$ accumulation rates under afforestation. The pines, planted in 1971, on the calcareous, sandy loam, till soil in Kemptville accumulated $\mathrm{C}$ at a rate of $0.56 \mathrm{MgC} \mathrm{ha} \mathrm{Cr}^{-1}$. No change was detected in the maple stand. The afforested, deciduous soil on a silt loam, calcareous till in Delaware, $\mathrm{OH}$ gained $0.15 \mathrm{Mg} \mathrm{C} \mathrm{ha}^{-1} \mathrm{yr}^{-1}$ over $50 \mathrm{yr}$ of succession.

Fifty years of afforestation on the sandy, Maumee, afforested, deciduous site resulted in $95.9 \mathrm{Mg}$ soil $\mathrm{C}$ ha $^{-1}$ compared with 88.2 in the native and 68.1 in the agricultural soil giving an accumulation rate of $0.58 \mathrm{Mg}$ soil C ha ${ }^{-1} \mathrm{yr}^{-1}$ in the deciduous site. The conifer soils lost $0.85 \mathrm{Mg} \mathrm{C} \mathrm{ha}^{-1} \mathrm{yr}^{-1}$. Such losses lead to the question of whether the sampling sites were on the same parent materials. The sand content in the A horizon of the afforested conifer (Table 5) was 93\%, the afforested deciduous was $90 \%$, the agricultural site was $89 \%$ with the native having the least sand (86\%). Subsurface horizons showed no significant textural or $\mathrm{pH}$ effects (Table 5). Other sites showed similar, small textural differences between land-use plots and few notable differences in $\mathrm{pH}$. At present we discount the possibility that land use over the 50-yr period altered the soil texture at these sites. All sites were chosen to be on similar topography. Until further sites are analyzed, we conclude that the major reason for the large SOC differences in the conifers was the result of pine afforestation.

The calcareous, Ontario site had similar tree biomass for both conifer and deciduous afforested sites that were significantly lower than the native. Biomass accumulation rates, per year, were high in the deciduous site because it was the youngest site at $21 \mathrm{yr}$ relative to the conifer planted $6 \mathrm{yr}$ earlier (Table 6). The Maumee afforested, deciduous site accumulated biomass $\mathrm{C}$ at a rate of $3.8 \mathrm{Mg} \mathrm{C} \mathrm{ha}^{-1} \mathrm{yr}^{-1}$. Inclusion of the soil-C raised the ecosystem accumulation rate to $4.4 \mathrm{Mg} \mathrm{C} \mathrm{ha}^{-1} \mathrm{yr}^{-1}$. The conifer biomass accumulated $\mathrm{C}$ at $2.4 \mathrm{Mg} \mathrm{C} \mathrm{ha}^{-1}$ $\mathrm{yr}^{-1}$, but because the soil lost $\mathrm{C}$ the ecosystem accumulation rate was $1.5 \mathrm{Mg} \mathrm{C} \mathrm{ha}^{-1} \mathrm{yr}^{-1}$.

The Delaware agricultural soils had $\mathrm{C} / \mathrm{N}$ ratios of 8 . The ratios were 9 at Maumee and 10 in the more northerly Kemptville site. The $\mathrm{C} / \mathrm{N}$ ratios of all afforested soils were more similar to the agricultural than to the native sites (Table 4). Carbon sequestration involves $\mathrm{N}$ accumulations in the plant biomass and in the SOM. We attributed the difference in total $\mathrm{N}$ between the agricultural ecosystem and the afforested one to $\mathrm{N}$ accumulation in the afforested site. The other possibility is that the agricultural soil lost this amount of $\mathrm{N}$ during the afforestation period. Soil samples from $50 \mathrm{yr}$ ago on this site are not available. Research on other similar agricultural sites (Lal et al., 1998; Dick and Jurkalski, 1998) has shown that agricultural soils are now at steady state or slightly increasing their SOC and soil organic $\mathrm{N}$ contents. This is attributed to better management and the two- to three-fold increases in crop residue returns that have occurred in the last $50 \mathrm{yr}$.

The ecosystem accumulation rate of $\mathrm{N}$ in the Ontario soils ranged between 0.02 and $0.03 \mathrm{Mg} \mathrm{N} \mathrm{ha}^{-1} \mathrm{yr}^{-1}$. The high ecosystem $\mathrm{N}$ accumulations of $0.08 \mathrm{Mg} \mathrm{N} \mathrm{ha}^{-1} \mathrm{yr}^{-1}$ in the deciduous, Maumee site and $0.054 \mathrm{Mg} \mathrm{N} \mathrm{ha}^{-1} \mathrm{yr}^{-1}$ at Delaware, $\mathrm{OH}$ (Table 6) leads us to question anew the controls on $\mathrm{N}$ inputs into these sites. Atmospheric $\mathrm{N}$ fixation in deciduous forests (aspen and maple) has been shown to approximate $0.001 \mathrm{Mg} \mathrm{N} \mathrm{ha}^{-1} \mathrm{yr}^{-1}(1 \mathrm{~kg}$ $\mathrm{N} \mathrm{ha}^{-1} \mathrm{yr}^{-1}$ ) (Knowles and O'Toole, 1975). There were no symbiotic $\mathrm{N}$ fixers noted in our sites. Atmospheric, wet deposition ranged from 5 to $7 \mathrm{~kg} \mathrm{~N} \mathrm{ha}^{-1} \mathrm{yr}^{-1}$ (NADP/ NTN, 2000; Canadian National Atmospheric Chemistry Precipitation Database, 2002). Dry deposition is usually thought to be no more than equal to the wet deposition. The sum of the above does not account for the accumulations shown in Table 6.

The Maumee soil showed the effects of lime additions

Table 4. Soil $\mathbf{C}$ and $\mathbf{N}$ storage $\dagger$ for agriculture, native, afforested deciduous, and afforested coniferous land-use types $\ddagger$ in three eastern North American sites.

\begin{tabular}{|c|c|c|c|c|c|c|}
\hline \multirow[b]{2}{*}{ Site } & \multirow[b]{2}{*}{ Land-use type } & \multicolumn{2}{|c|}{ Pool size§ } & \multirow[b]{2}{*}{ C/N ratio§ } & \multicolumn{2}{|c|}{ Accumulation rates } \\
\hline & & Soil C & Soil $\mathbf{N}$ & & C & $\mathbf{N}$ \\
\hline & & $-M$ & 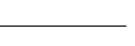 & & $-\mathbf{M}$ & $\mathbf{r}^{-1}$ \\
\hline \multirow{4}{*}{ Kemptville, Ontario } & Agriculture & $78.9(6.2)^{\mathrm{a}}$ & $7.7(0.7)^{\mathrm{a}}$ & $10.3(0.1)^{\mathrm{a}}$ & & \\
\hline & Native & $78.0(8.0)^{\mathrm{a}}$ & $5.4(0.6)^{a}$ & $14.4(0.1)^{\mathrm{c}}$ & & \\
\hline & Afforested Deciduous & $76.5(6.9)^{\mathrm{a}}$ & $6.9(0.5)^{\mathrm{a}}$ & $11.0(0.3)^{b}$ & -0.07 & -0.036 \\
\hline & Afforested Coniferous & $94.1(9.2)^{\mathrm{a}}$ & $7.9(1.2)^{a}$ & $12.1(0.8)^{a, b}$ & 0.56 & 0.007 \\
\hline \multirow{5}{*}{$\begin{array}{l}\text { Maumee State Forest } \\
\text { Ohio (1950) }\end{array}$} & & & & & & \\
\hline & Agriculture & $68.1(9.7)^{\mathrm{b}, *}$ & $7.1(0.6)^{b, c}$ & $9.6(0.6)^{a, *}$ & & \\
\hline & Native & $88.2(8.3)^{b}$ & $6.4(0.3)^{b}$ & $13.8(1.4)^{\mathrm{b}, *}$ & & \\
\hline & Afforested Deciduous & 95.9(11.6) $)^{\mathrm{b}, *}$ & $8.2(0.5)^{\mathrm{c}}$ & $11.6(0.6)^{\mathrm{a}, \mathrm{b}, *}$ & 0.58 & 0.023 \\
\hline & Afforested Coniferous & $27.4(0.7)^{a}$ & $2.2(0.1)^{a}$ & $12.2(0.2)^{a, *, b}$ & -0.85 & -0.102 \\
\hline \multirow{4}{*}{$\begin{array}{l}\text { Delaware Wildlife Area } \\
\text { Ohio (1950) }\end{array}$} & & & & & & \\
\hline & Agriculture & $106.4(2.5)^{a}$ & $12.5(0.3)^{\mathrm{a}}$ & $8.5(0.1)^{\mathrm{a}, \mathrm{b}, *}$, & & \\
\hline & Native & $153.4(5.2)^{b}$ & $15.8(1.2)^{\mathrm{a}}$ & $9.9(0.6)^{b}, *$ & & \\
\hline & Afforested Deciduous & $113.8(6.4)^{a}$ & $13.7(0.5)^{\mathrm{a}}$ & $8.3(0.2)^{a}$ & 0.15 & 0.025 \\
\hline
\end{tabular}

$\dagger$ Measured to 1-m depth corrected for equivalent weight at all sites except Kemptville, Ontario, which was sampled to a depth of $41 \mathrm{~cm}$.

$¥$ Maumee, Ohio sites were afforested in 1950, Delaware, Ohio site was transferred from agriculture in 1950, the Kemptville coniferous site was planted in 1970 and the deciduous site in 1977.

$\S$ Pool means followed by standard error in parentheses. Within site pool means followed by the same letter did not differ significantly among land-use types at $p \leq 0.05$. Within site pool means followed by the same letter with an asterisk differed significantly at $0.05 \leq p \leq 0.10$ among land-use types. 
Table 5. Soil sand, silt and clay content, and pH for agriculture, native, afforested deciduous and afforested coniferous land use types in three eastern North American sites.

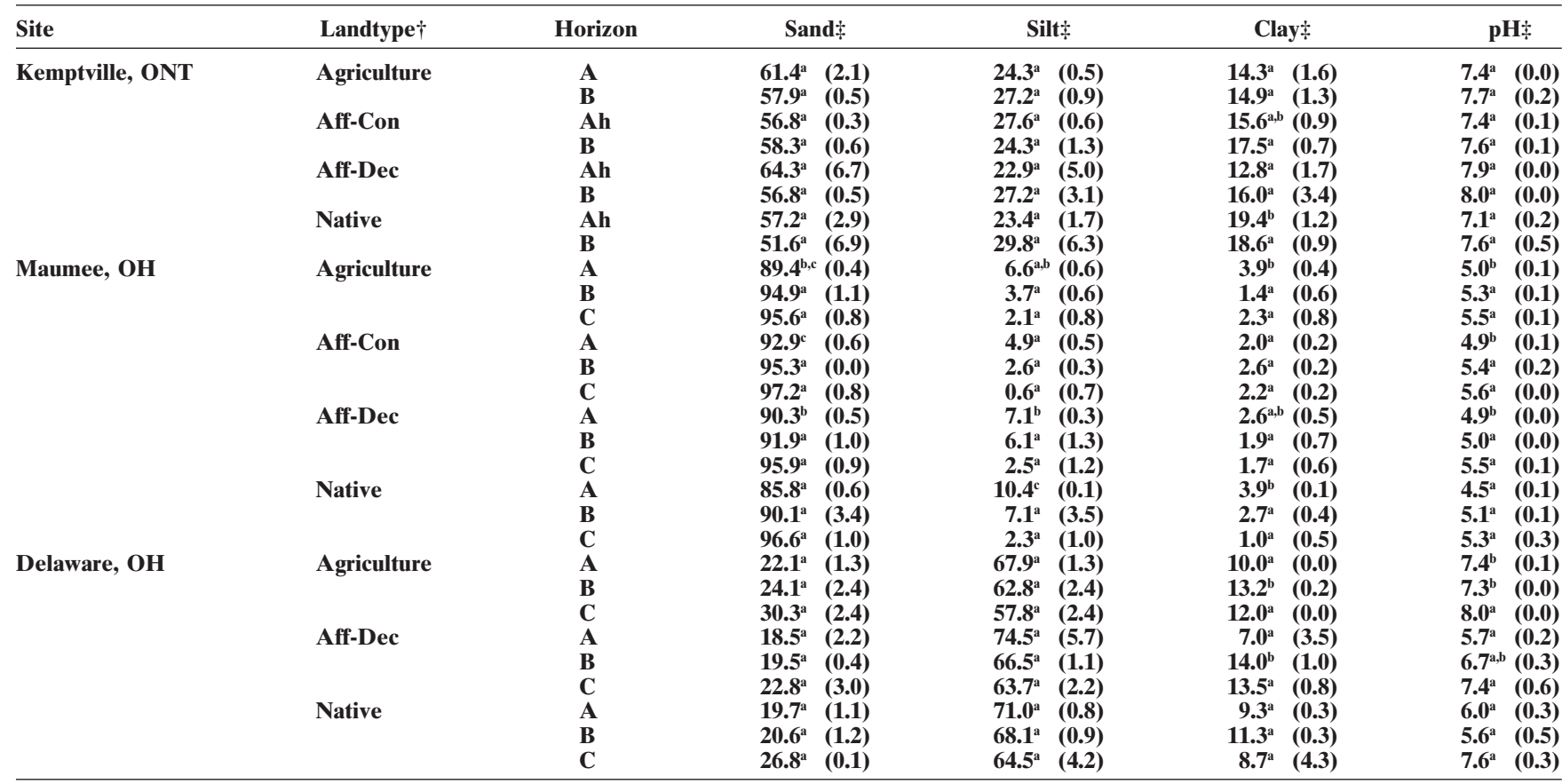

$\uparrow$ Aff-Dec $=$ Afforested Deciduous/Aff-Con $=$ Afforested Coniferous.

+ Pool means followed by standard error in parentheses. Within site pool means for sand, silt, clay or pH followed by the same letter did not differ significantly among land-use types for each horizon separately at $p \leq \mathbf{0 . 0 5}$ except for the B horizon of the Delaware Aff-Dec, which differed at $0.10 \leq$ $p \leq \mathbf{0 . 0 5}$.

on the $\mathrm{Ca}$ content of the agricultural site (Table 7) without significant alterations to soil $\mathrm{pH}$ by afforestation with either conifers or deciduous species (Table 5). The other two sites were on calcareous parent material and there were no differences in $\mathrm{Ca}$ or $\mathrm{Mg}$ with land-use type although the Delaware site appeared to have more dolomite (with $\mathrm{Mg}$ ) than the Kemptville site. The relationships of soil $\mathrm{C}$ and $\mathrm{N}$ contents to soil cations were evaluated by including a similar set of sites (agriculture, afforested deciduous, and coniferous and native) collected using similar methodology from central Michigan (Morris et al., 2003). This resulted in a cross-site comparison that included five conifer, six native, six deciduous afforested, and nine agricultural sites. Soil C and N contents were unrelated to soil $\mathrm{P}$ contents with the exception of profile $\mathrm{C}$ in the coniferous sites (Table 8).

Table 6. Total ecosystem $\mathrm{C}$ and $\mathrm{N}$ content $\dagger$ for native and afforested land-use types in three sites in North America and annual accumulation ratesł for afforested deciduous and coniferous land-use types.

\begin{tabular}{|c|c|c|c|c|c|c|c|c|}
\hline & \multicolumn{3}{|c|}{ Kemptville, Ontario } & \multicolumn{3}{|c|}{ Maumee, OH } & \multicolumn{2}{|c|}{ Delaware, ОН } \\
\hline & Native & Aff DecII & Aff Con\# & Native & Aff Dec & Aff Con & Native & Aff Dec \\
\hline \multicolumn{9}{|c|}{ Carbon, $\mathrm{Mg} \mathrm{ha}^{-1}$} \\
\hline \multicolumn{9}{|l|}{ Biomass§ } \\
\hline Overstory & 103 & 76 & 79 & 168 & 160 & 97 & 102 & 77 \\
\hline Roots & 16 & 12 & 13 & 26 & 24 & 16 & 14 & 12 \\
\hline Total & 119 & 88 & 92 & 194 & 184 & 113 & 119 & 89 \\
\hline Rate, $\mathbf{y r}^{-1}$ & - & 4.2 & 3.2 & - & 3.8 & 2.4 & - & 2.0 \\
\hline \multicolumn{9}{|l|}{ Ecosystem } \\
\hline Rate, $\mathrm{yr}^{-1}$ & - & 4.1 & 3.8 & - & 4.4 & 1.5 & - & 2.2 \\
\hline \multicolumn{9}{|c|}{ Nitrogen, $\mathbf{M g ~ h a}^{-1}$} \\
\hline \multirow{2}{*}{\multicolumn{9}{|c|}{ Biomass }} \\
\hline & & & & & & & & \\
\hline Roots & 0.28 & 0.21 & 0.09 & 0.46 & 0.42 & 0.11 & 0.26 & 0.21 \\
\hline Total & 1.91 & 1.42 & 0.42 & 3.06 & 2.92 & 0.51 & 1.88 & 1.41 \\
\hline Rate, $\mathrm{yr}^{-1}$ & - & 0.07 & 0.02 & - & 0.06 & 0.01 & - & 0.03 \\
\hline \multicolumn{9}{|l|}{ Ecosystem } \\
\hline Rate, $\mathrm{yr}^{-1}$ & - & 0.03 & 0.02 & - & 0.08 & -0.09 & - & 0.05 \\
\hline
\end{tabular}

$\dagger$ Ohio sites sampled in 1998 and Ontario in 1999.

$¥$ Maumee, Ohio sites were afforested in 1950, Delaware, Ohio site was transferred from agriculture in 1950, the Kemptville coniferous site was planted in 1970 and the deciduous site in 1977.

§ Above and belowground biomass to $\mathrm{C}$ conversions made with factors from Birdsey (1992), C:N ratios of 63 for deciduous overstory, 57 for deciduous roots (Kaczmarek et al., 1995), C:N ratios of 240:1 coniferous overstory and 150 for roots (Pregitzer and Palik, 1997).

II Aff-Dec $=$ Afforested Deciduous.

\# Aff-Con = Afforested Coniferous. 
Table 7. Extractable soil $\mathrm{P}, \mathrm{K}, \mathrm{Ca}$, and $\mathrm{Mg} \dagger$ for agriculture, native, afforested deciduous and afforested coniferous land-use typesł in three eastern North American sites.

\begin{tabular}{|c|c|c|c|c|c|}
\hline \multirow[b]{2}{*}{ Site } & \multirow[b]{2}{*}{ Land-use type } & \multicolumn{4}{|c|}{ Pool Size§ } \\
\hline & & Soil $\mathbf{P}$ & Soil $\mathrm{K}$ & Soil Ca & Soil Mg \\
\hline & & & & & \\
\hline \multirow{4}{*}{$\begin{array}{l}\text { Kemptville } \\
\text { Ontario }\end{array}$} & Agriculture & $322(39)^{b}$ & $547(90)^{b}$ & $4753(181)^{\mathrm{a}}$ & $1307(29)^{a}$ \\
\hline & Native & $5(1)^{a}$ & $119(12)^{\mathrm{a}}$ & $4945(735)^{\mathrm{a}}$ & $1418(195)^{2}$ \\
\hline & Afforested deciduous & $33(9)^{a}$ & $174(11)^{\mathrm{a}}$ & $4646(302)^{a}$ & $1231(60)^{a}$ \\
\hline & Afforested coniferous & $21(6)^{a}$ & $153(18)^{a}$ & $4826(238)^{a}$ & $1493(60)^{a}$ \\
\hline \multirow{4}{*}{$\begin{array}{l}\text { Maumee State forest } \\
\text { Ohio (1950) }\end{array}$} & Agriculture & $1051(112)^{\mathrm{c}}$ & $613(30)^{b}$ & $3090(903)^{b}$ & $114(35)^{\mathrm{a}}$ \\
\hline & Native (Maple) & $687(57)^{b}$ & $255(8)^{a}, *$ & $950(139)^{a}$ & $150(64)^{a}$ \\
\hline & Afforested deciduous (Maple) & $311(19)^{a}$ & $308(20)^{\mathrm{a}}$ & $1226(132)^{a}$ & $230(51)^{a, b}$ \\
\hline & Afforested coniferous (Pine) & $840(17)^{b}$ & $316(23)^{a, *}$ & $1171(147)^{a}$ & $299(21)^{b}$ \\
\hline \multirow{3}{*}{$\begin{array}{l}\text { Delaware Wildlife area } \\
\text { Ohio (1950) }\end{array}$} & Agriculture & $92(7)^{a}$ & $1225(54)^{\mathrm{a}}$ & $43248(1633)^{a}$ & $6734(397)$ \\
\hline & Native (Maple) & $125(51)^{a}$ & $1259(149)^{\mathrm{a}}$ & $37658(6742)^{a}$ & $5073(850)^{2}$ \\
\hline & Afforested deciduous (Maple) & $74(32)^{a}$ & $2470(689)^{a}$ & $28680(3911)^{a}$ & $5869(248)^{2}$ \\
\hline
\end{tabular}

$\uparrow$ Measured to 1-m depth corrected for equivalent weight at all sites except Kemptville, Ontario, which was sampled to a depth of $41 \mathrm{~cm}$.

\$ Maumee, Ohio sites were afforested in 1950, Delaware, Ohio site was transferred from agriculture in 1950, the Kemptville coniferous site was planted in 1970 and the deciduous site in 1977.

\$ Pool means followed by standard error in parentheses. Within site pool means followed by the same letter did not differ significantly among land-use types at $p \leq 0.05$. Within site pool means followed by the same letter with an asterisk differed significantly at $0.05 \leq p \leq 0.10$ among land-use types.

Profile $\mathrm{K}$ content was correlated with both the $\mathrm{C}$ and $\mathrm{N}$ content of the mixed-deciduous native sites and the afforested deciduous sites but not the coniferous sites. The relationship of soil $\mathrm{Ca}$ content to total profile $\mathrm{C}$ for the agricultural sites had an $r^{2}$ of 0.50 whereas that of profile $\mathrm{N}$ was 0.61 . The quantity of profile-extractable $\mathrm{Ca}$ explained much of the variation in profile $\mathrm{C}$ and $\mathrm{N}$ of the forested sites accounting for 49 to $90 \%$ of the variation in these elements (Table 8). The effects of $\mathrm{Mg}$ on soil $\mathrm{C}$ and $\mathrm{N}$ were similar to that of $\mathrm{Ca}$. The relationship of soil nutrient content to tree biomass was unrelated to $\mathrm{Ca}$ (data not shown).

The effects of different sites and vegetation types on soil nutrient cation and $\mathrm{C}$ and $\mathrm{N}$ contents can be better

Table 8. Relationship $\left(r^{2}\right)$ of extractable soil $\mathrm{P}, \mathrm{K}, \mathrm{Ca}$, and $\mathrm{Mg}$ to soil $\mathbf{C}$ and $\mathbf{N}$ content $\dagger$ for agriculture, native, afforested deciduous and afforested coniferous land-use types $\neq$ in four eastern North American sites.

\begin{tabular}{|c|c|c|c|c|}
\hline & $\mathbf{P}$ & $\mathbf{K}$ & $\mathrm{Ca}$ & Mg \\
\hline \multicolumn{5}{|c|}{ Agricultural sites } \\
\hline Profile C & NS\# & 0.38 & 0.50 & 0.40 \\
\hline Profile N & NS & 0.24 & 0.61 & 0.53 \\
\hline \multicolumn{5}{|c|}{ Native sites } \\
\hline Profile C & NS & 0.71 & 0.71 & 0.68 \\
\hline Profile N & NS & 0.86 & 0.78 & 0.71 \\
\hline \multicolumn{5}{|c|}{ Deciduous sites } \\
\hline Profile $\mathrm{C}$ & NS & 0.54 & 0.68 & 0.53 \\
\hline Profile N & NS & 0.71 & 0.90 & 0.81 \\
\hline $\mathbf{C} / \mathbf{N}$ & NS & 0.45 & 0.54 & 0.62 \\
\hline$\delta \mathbf{C} \S$ & 0.39 & NS & NS & NS \\
\hline$\delta \mathrm{NI}$ & $\mathbf{0 . 3 3}$ & NS & NS & NS \\
\hline \multicolumn{5}{|c|}{ Coniferous sites } \\
\hline Profile C & 0.50 & NS & 0.70 & 0.76 \\
\hline Profile N & 0.32 & NS & 0.49 & 0.68 \\
\hline C/N & NS & NS & NS & NS \\
\hline$\delta \mathbf{C} \S$ & 0.32 & NS & 0.77 & 0.49 \\
\hline$\delta \mathrm{N}$ & NS & NS & 0.53 & 0.36 \\
\hline
\end{tabular}

$\dagger$ Measured to 1-m depth corrected for equivalent weight at all sites except Kemptville, Ontario, which was sampled to a depth of $41 \mathrm{~cm}$.

$\$$ Maumee, Ohio sites were afforested in 1950, Delaware, Ohio site was transferred from agriculture in 1950, the Kemptville coniferous site was planted in 1970 and the deciduous site in 1977. Russ Forest deciduous afforested sites were planted between 1943 and 1946. The coniferous sites were planted in 1938, 1943, 1966.

$\S \delta C=$ soil $\mathbf{C}$ in afforested site - soil $\mathbf{C}$ in agricultural site.

II $\delta \mathbf{N}=$ soil $\mathbf{N}$ in afforested site - soil $\mathbf{N}$ in agricultural site.

\# Not Significant. characterized by subtracting the $\mathrm{C}$ and $\mathrm{N}$ contents of the agricultural site from that of the adjacent afforested site on the same soil type. The use of the agricultural soils as controls to normalize site data is shown as the $\delta \mathrm{C}$ and $\delta \mathrm{N}$ values in Table 8 . The $\mathrm{P}$ levels showed some effect on $\delta \mathrm{C}$ and $\delta \mathrm{N} ; \mathrm{K}$ had no effect. Calcium was an important factor affecting the $\delta \mathrm{C}\left(r^{2}=0.77\right)$ and $\delta \mathrm{N}$ $\left(r^{2}=0.53\right)$ on the conifer but not the deciduous sites.

\section{DISCUSSION}

Our comparison of two tracer and an incubation method on the same soil samples gave related MRT values that differed by three orders of magnitude. This is interpreted to mean that all the methods gave meaningful data but sampled different portions of the SOC continuum. The MRT data supplied by the plant replacement experiments reflect the fact that these experiments have been in place for a few decades (Six and Jastrow, 2002). The use of extended laboratory incubation provides information on the SOC that has been mineralized over a few hundred-day periods. When extrapolated to the field with $\mathrm{Q}_{10}$ relationships, the laboratory derived MRTs were highly related to the estimates based on field data, but only 27 to $33 \%$ as large. The MRT of the ${ }^{13} \mathrm{C}$ field data after a 10 - to 35 -yr exposure should be higher, because some of the ${ }^{13} \mathrm{C}$ should by that time be in the resistant fraction and would not be susceptible to mineralization during laboratory incubation. The ${ }^{14} \mathrm{C}$ dating reflects thousands of years of soil pedogenesis; MRTs from this method are 176 times as great as those obtained in 10 - to 35 -yr old ${ }^{13} \mathrm{C}$-plant replacement studies. The ${ }^{14} \mathrm{C}$ dates for the whole soil now also reflect bomb $-{ }^{14} \mathrm{C}$ inputs into the atmosphere during the last $50 \mathrm{yr}$ (Trumbore et al., 1996). Acid hydrolysis removes much of this younger material. The nonhydrolyzable $\mathrm{C}$ that comprises approximately $50 \%$ of the total soil $\mathrm{C}$ was on average $1400 \mathrm{yr}$ older than the SOC in surface soils and 3000 to $5000 \mathrm{yr}$ older in subsurface samples (Paul et al., 2001a). This C will become only slowly labeled in tracer experiments of short duration.

We conclude that the highly correlated data, from different experimental approaches shows that the three 
techniques are sampling different parts of a SOM continuum. We further interpret this to mean that the same controls of SOM dynamics (Fig. 1) are affecting all parts of this continuum. The above lends credence to the presently utilized analytical approaches. This conclusion is further supported by another study (Paul et al., 1999) that incorporated into the Century model (Parton et al., 1988: Paustian et al., 1992) pool sizes and fluxes analytically determined with acid hydrolysis, ${ }^{14} \mathrm{C}$ dating and extended incubation to predict field $\mathrm{CO}_{2}$ evolution rates. The predicted rates were related $\left(r^{2}=0.55\right)$ to those measured under field conditions over a 2-yr period.

Our results show a great range in the amount of soil C sequestered following afforestation $(-0.85$ to $0.58 \mathrm{Mg}$ $\mathrm{C} \mathrm{ha}^{-1} \mathrm{yr}^{-1}$ ). This calculation is based on the premise that the present agricultural site is representative of the afforested site at the time it went to trees. It also is dependent on the variability found in different fields of the same land-use type. Morris et al. (2003) sampling multiple fields of different land uses found that agricultural fields managed by different farmers in a single county could vary by a factor of two in their SOM contents. This variation was associated with the yield of the crops and thus the residue inputs. In sampling sites where multiple fields were not available, we restricted our sampling of agricultural fields to those that had crop yields and SOM contents that approximated the county average. The extensive loss of SOM on pine tree growth on former agricultural land, observed at the Maumee site, is not without precedent (Pregitzer and Palik, 1997).

The afforested soils had $\mathrm{C} / \mathrm{N}$ ratios that were more similar to the agricultural than to the native sites. The amount of $\mathrm{N}$ sequestered or lost was still closely associated with the $\mathrm{C}$ dynamics, showing that similar controls apply to both. Some sites had $\mathrm{N}$ levels that are difficult to explain with present knowledge of biological $\mathrm{N}$ fixation or atmospheric inputs. We determined a relationship between $\mathrm{Ca}$ and other nutrients and SOM accumulations. The finding that soil $\mathrm{Ca}$ was related to soil $\mathrm{C}$ and $\mathrm{N}$ on the agricultural sites may be an indication of better management resulting in higher yields and residue inputs on the more often limed and thus higher Ca soil. These results and recent papers evaluating the effects of $\mathrm{Ca}$ on SOM sequestration (Baldock and Nelson, 2000; Clough and Skjemstad, 2000) suggest that the potential for $\mathrm{Ca}$ additions to some forests such as those on Alfisols should be further investigated for SOC sequestration. The effects of $\mathrm{Ca}$ can in part be attributed to the effects of soil mixing due to the greater abundance of earthworms we observed in high, Ca Alfisols. Other explanations include the stabilizing effect of $\mathrm{Ca}$ on humic compounds and aggregates through the formation of Ca-organic-mineral linkages (Stevenson, 1994). Thin carbonate coatings on fresh residues have been shown to decrease decomposition (Krull et al., 2001). Correlation studies cannot separate cause and effect relationships. It could be argued that the increased SOM caused an increase in the soil Ca levels. This is difficult to justify because external sources of $\mathrm{Ca}$ are not as available as is the case with $\mathrm{C}$ and $\mathrm{N}$. Weathering of $\mathrm{Ca}$ from soil minerals would be much slower than the time frame of these experiments.

We found sampling and analysis using verifiable, reproducible techniques can greatly assist in interpretation of controls on SOM dynamics. Verification of approaches by independent assays and use of coordinated, physical, chemical, and biological analysis on well sampled, representative management sites provides a level of confidence in the results. Pool sizes and fluxes determined with established analytical techniques when incorporated into appropriate models allow one to further test hypothesis and extrapolate data from a limited number of sites to broader geographical units.

\section{ACKNOWLEDGMENTS}

This research was funded by U.S. Department of Energy Grant: Soil organic matter dynamics and management: Decision-making in an enriched $\mathrm{CO}_{2}$ environment (DE-FGO294ER61924), awarded to Michigan State University with a subcontract to Colorado State University. We thank Sven Bohm and Shawel Haile-Mariam for assistance in sampling and data analysis. Katherine DeVries helped with forest inventories. Ohio site managers Don Schmenk and Bob O'Donnell, Michigan site manager Greg Kowaleski and Kemptville, Ontario, College Director Bill Curnoe were especially helpful in supplying access to their sites and a wealth of historical data. Agriculture Canada, soil surveyor Dave Kroetsch assisted in site characterization and sampling of the Kemptville site.

\section{REFERENCES}

Baldock, J.A., and P.N. Nelson. 2000. Soil Organic Matter. p. B25-B84. In M.K. Sumner (ed.) Handbook of soil science. CRC Press, Boca Raton, FL.

Birdsey, R.A. 1992. Carbon storage and accumulation in United States forest ecosystems. GTR WO-59. Northeastern Forest Experiment Station, Radnor, PA.

Boerner, R.E.J., and S.D. Koslowsky. 1989. Microsite variations in soil chemistry and nitrogen mineralization in a beech-maple forest. Soil Biol. Biochem. 21:795-801.

Boone, R.D., D.F. Grigal, P. Sollins, R.S. Ahrens, and D.E. Armstrong. 1999. Soil sampling preparation, archiving and quality control. p. 3-28. In G.P. Robertson et al. (ed.) Standard soil methods for long-term ecological research. Oxford University Press, Oxford, UK.

Boutton, T.W. 1996. Stable carbon isotope ratios of soil organic matter and their use as indicators if vegetation and climate change. p. 47-82. In T.W. Boutton and S. Yamasaki (ed.) Mass spectrometry of soils. Marcel Dekker, New York.

Cambardella, C.A., and E.T. Elliott. 1992. Particulate soil organicmatter changes across a grassland cultivation sequence. Soil Sci. Soc. Am. J. 56:777-783.

Campbell, C.A., E.A. Paul, D.A. Rennie, and K.J. McCallum. 1967. Factors affecting the accuracy of the carbon dating method of soil humus studies. Soil Sci. 104:81-85.

Canadian National Atmospheric Chemistry Precipitation Database. 2002. Environment Canada. Meteorological Service of Canada, Toronto, Ontario, Canada.

Clough, A., and J. Skjemstad. 2000. Physical and chemical protection of soil organic carbon in three agricultural soils with different contents of calcium carbonate. Aust. J. Soil Res. 38:1005-1016.

Coleman, D.C., and B. Fry. 1991. Carbon isotope techniques. Academic Press. San Diego, CA.

Collins, H.P., E.T. Elliott, K. Paustian, L.E. Bundy, W.A. Dick, D.R. Huggins, A.J.M. Smucker, and E.A. Paul. 2000. Soil carbon pools and fluxes in long-term Corn Belt agroecosystems. Soil Biol. Biochem. 32:157-168.

Collins, H.P., R.L. Blevins, L.G. Bundy, G.R. Christenson, W.A. Dick, D.R. Huggins, and E.A. Paul. 1999. Soil carbon dynamics in cornbased agroecosystems: Results from carbon-13 natural abundance. Soil Sci. Soc. Am. J. 63:584-591. 
Dick, W.A., and J.T. Jurkalski. 1998. No till production agriculture and carbon sequestration in a Typic Fragiudalf soil of Northeastern Ohio. p. 59-72. In R. Lal et al. (ed.) Management of carbon sequestration in soils. CRC Press, Boca Raton FL.

Ellert, B., and E.G. Gregorich. 1996. Storage of C, N, and P in cultivated and adjacent forest soils of Ontario. Soil Sci. 1619:587-603.

Elliott, E.T., J.W. Heil, E.F. Kelly, and H.C. Monger. 1999. Soil structural and other physical properties. p. 74-85. In G.P. Robertson et al. (ed.) Standard soil methods for long-term ecological research. Oxford University Press, Oxford, UK.

Frank, K., D. Beegle, and J. Denning. 1998. Phosphorus. p. 21-30. In J.R. Brown (ed.) Recommended chemical soil test procedures for the North Central Region. Missouri Agricultural Experiment Station SB1001. University of Missouri, Columbia.

Goh, K.M., J.D. Stout, and B.J. O'Brien. 1989. The significance of fractionation in dating the age and turnover of soil organic matter. N.Z J. Sci 27:69-72.

Jenny, J. 1941, Factors of soil formation, McGraw-Hill London. U.K.

Kaczmarek, D.J., K.S. Rodkey, R.T. Reber, P.E. Pope, and F. Ponder, Jr. 1995. Carbon and nitrogen pools in oak-hickory forests. p. 79-93. In K.W. Gottschank and S.L.C. Fosbroke (ed.) Proc. 10th central hardwood for. conf. GTR NE-197. Morgantown, WV. 1995.

Knowles, R., and P. O'Toole. 1975. Acetylene reduction assay of ambient $\mathrm{PO}_{2}$ of field and forest soils: Laboratory and field core studies. p. 285-294. In W.D.P. Stewart (ed.) Nitrogen fixation by free living microorganisms. Cambridge University Press, Cambridge, UK.

Kononova, M.M. 1966. Soil organic matter. Its nature. Its role in soil formation and soil fertility. 2nd ed., T. Nowalski and C. Newman (Translators) Pergammon Press Oxford. U.K.

Krull, E., J. Baldock, and J. Skjemstad. 2001. Soil texture effects on decomposition and soil carbon storage. p. 103-110. In M.U.F. Kirschbaum, and R. Mueller (ed.) Net ecosystem exchange. Cooperative Research Centre for Greenhouse Accounting. Canberra, Australia.

Lal, R., J.M. Kimble, R.F. Follett, and C.V. Cole. (ed.). 1998. The potential for U.S. cropland to sequester carbon and mitigate the greenhouse effect. Ann Arbor Press, Chelsea, MI.

Leavitt, S.W., R.F. Follett, and E.A. Paul. 1997. Estimation of slow and fast-cycling soil organic carbon pools from $6 \mathrm{~N} \mathrm{HCI} \mathrm{hydrolysis.}$ Radiocarbon 38:231-239.

Morris, S.J., S. Bohm, S. Haile-Mariam, and E.A. Paul. 2003. C and $\mathrm{N}$ sink capacity of afforested agricultural soils. In press.

Morris, S.J. 1999. Spatial distribution of fungal and bacterial biomass in southern Ohio hardwood forest soils: Fine scale variability and microscale patterns. Soil Biol. Biochem. 31:1375-1386.

Mulla, D.J., and A.B. McBratney. 2000. Soil spatial variability. p. A321-A352. In M.K. Sumner (ed.) Handbook of soil science. CRC Press, Boca Raton, FL.

NADP/NTN. 2000. http://nadp.sws.uiuc.edu/default.html.

Parton, W.J., J.W.B. Stewart, and C.V. Cole. 1988. Dynamics of C, N, P, and S in grassland soils: A model. Biogeochemistry 5:109-131.

Paul, E.A., D. Harris, H.P. Collins, U. Schulthess, and G.P. Robertson.
1999. Evolution of $\mathrm{CO}_{2}$ and soil carbon dynamics in biologically managed, row crop agroecosytems. Appl. Soil Ecol. 11:53-65.

Paul, E.A., H.P. Collins, and S.W. Leavitt. 2001a. Dynamics of resistant soil carbon of Midwestern agricultural soils measured by naturally-occurring ${ }^{14} \mathrm{C}$ abundance. Geoderma 104:239-265.

Paul, E.A., S.J. Morris, and S. Böhm. 2001b. The determination of soil C pool sizes and turnover rates: Biophysical fractionation and tracers. p. 193-206 In. R. Lal et al. (ed.). Assessment methods for soil C pools. CRC Press, Boca Raton, FL.

Paustian, K., W.J. Parton, and J. Persson. 1992. Modeling of soil organic matter in organic amended and $\mathrm{N}$ fertilized long-term experiments. Soil Sci. Soc. Am. J. 56:476-488.

Post, W.M., and K.C. Kwon. 2000. Soil carbon sequestration and landuse change: Processes and potential. Global Change Biology 6: 317-327.

Pregitzer, K.S., and B.J. Palik. 1997. Changes in ecosystem carbon 46 years after establishing red pine (Pinus resinosa Ait.) on abandoned agricultural land in the Great Lakes region. p. 263-272. In E.A. Paul et al. (ed.) Soil organic matter in temperate agroecosystems Long-term experiments in North America. CRC Press, Boca Raton, FL.

SAS. 1995. Statistical analysis system user's guide: Statistics. Version 6.2. SAS Institute, Cary, NC.

Six, J., P. Callewaert, S. Lenders, S. DeGryze, S.J. Morris, E.G. Gregorich, E.A. Paul, and K. Paustian. 2002. Measuring and understanding carbon storage in afforested soils by physical fractionation. Soil Sci. Soc. Am. J. 66:1981-1987.

Six. J., and J.D. Jastrow. 2002. Soil organic matter turnover. p. 936-942. In R. Lal (ed.) Encyclopedia of soil science. CRC Press, Boca Taton, FL.

Sollins, P., C. Glassman, E.A. Paul, C. Swanston, K. Lajtha, J. Heil, and T.E. Elliott. 1999. Soil carbon and nitrogen pools and fractions. p. 89-105. In G.P. Robertson et al. (ed.) Standard soil methods for long-term ecological research. Oxford University Press, Oxford, UK.

Stevenson, F.J. 1994. Humus chemistry. 2nd ed. John Wiley and Sons. New York.

Stoyan, H., H. De-Polli, S. Böhm, G.P. Robertson, and E.A. Paul. 2000. Spatial variability of soil respiration and related soil properties at the plant scale. Plant Soil 219:1-12.

Tritton, L.M., and J.W. Hornbeck. 1982. Biomass equations for major tree species of the northeast. USDA For. Serv. Gen. Tech. Rep. NE-69. Broomall, PA.

Trumbore, S.E., O.A. Chadwick and R. Amundson. 1996. Rapid exchange between soil carbon and atmospheric carbon dioxide driven by temperature change. Science 272:393-396.

Warncke, D., and J.R. Brown. 1998. Potassium and other basic cations. p. 31-34. In J.R. Brown (ed.) Recommended chemical soil test procedures for the North Central Region. Missouri Agricultural Exp. Station SB1001. North Central Regional Research Publication No. 221. University of Missouri, Columbia.

Zinke, P.J. 1962. The pattern of influence of individual forest trees on soil properties. Ecology 43:130-133.

\section{NEW BOOKS RECEIVED}

BIOAVAILABILITY, TOXICITY AND RISK RELATIONSHIPS IN ECOSYSTEMS. Edited by $R$. Naidu, V.V.S.R. Gupta, S. Rogers, R.S. Kookana, N.S. Bolan, and D.C. Adriano. Science Publishers, Inc., PO Box 699, Enfield, NH 03748. ISBN 1-57808-192-0.

MULTIVARIATE ANALYSIS OF ECOLOGICAL DATA USING CANOCO. Jan Jep̌̌ and Petr Šmilauer. Cambridge University Press, 40 West 20th Street, New York, NY 100114211. 2003. Hard copy: ISBN 0-521-81409-X., \$110.00. Paperback: ISBN 0521-89108-6, \$42.00.
SCALING METHODS IN SOIL PHYSICS. Edited by Yakov Pachepsky, David E. Radcliffe, and H. Magdi Selim. CRC Press LLC., 2000 N.W. Corporate Blvd., Boca Raton, FL 33431. 2003. ISBN 0-8493-1374-0.

SEEPAGE IN SOILS: PRINCIPLES AND APPLICATIONS. Lakshmi N. Reddi. J. Wiley and Sons, 111 River Street, 4th Floor, Hoboken, NJ 07030. 2003. ISBN 0-47135616-6.

TREES, CROPS AND SOIL FERTILITY: CONCEPTS AND RESEARCH METHODS. Edited by G. Schroth and F.L. Sinclair. CABI Publishing, 44 Brattle Street, 4th Floor, Cambridge, MA 02138. 2003. ISBN 0-85199-593-4. 


\title{
ERRATUM
}

Snow Removal and Ambient Air Temperature Effects of Forest Soil Temperatures in Northern Vermont

\author{
K.L.M. Decker, D. Wang, C. Waite, and T. Scherbatskoy
}

Soil Sci. Soc. Am. J. 67:1234-1242 (2003)

On page 1237, Fig. 2 is incorrect. The correct Fig. 2 is shown below (The correct Fig. 2 is included in the online article.).

a)
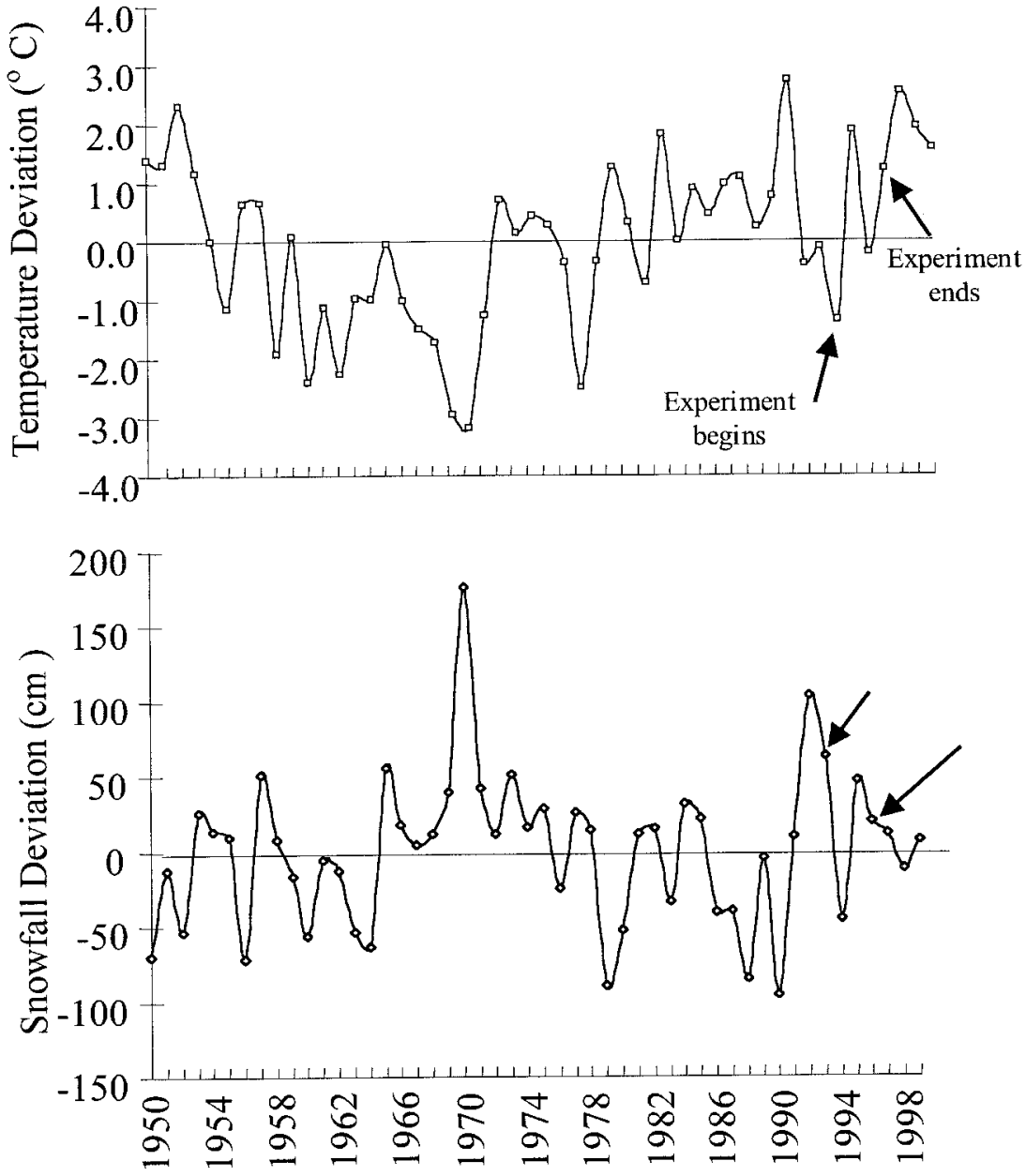

Starting year of winter

Fig. 2. Deviation from normal average winter (a) temperature and (b) snowfall for the South Burlington Airport (VT) for the past 50 yr. Winters are defined as 1 December through 30 April. (Data compiled from the National Climatic Data Center; www.ncdc.noaa.gov) 